Tạp chí Các Khoa học về Trái Đất, 38 (1), 131-142

\begin{tabular}{c} 
Viện Hàn lâm Khoa học và Công nghệ Việt Nam \\
Tạp chí Các Khoa học về Trái Đất \\
(VAST) \\
Website: http://www.vjs.ac.vn/index.php/jse \\
\hline
\end{tabular}

\title{
Nghiên cứu, đánh giá trượt lở bờ và bồi lắng lòng hồ Hòa Bình
}

\author{
Bùi Văn Thơm*1, Phạm Quang Sơn ${ }^{1}$, Phạm Văn Hùng ${ }^{1}$, Ngô Thị Vân Anh ${ }^{2}$ \\ ${ }^{I}$ Viện Địa chất, Viện Hàn lâm Khoa học và Công nghệ Việt Nam \\ ${ }^{2}$ Viện Khoa học Khi tuợng Thủy văn và Biến đổi khi hậu
}

Chấp nhận đăng: 10 - 2 - 2016

ABSTRACT

Research assessment landslide and sedimentation of Hoa Binh hydropower reservoir

This work presents the research results lakeshore landslides and sedimentation Hoa Binh hydropower reservoir by synthetic methods analyze high-resolution satellite images, survey, surveying and mapping.

Lakeside landslide occurred under different levels in space. Landslides lakeshore strong level includes the following sections: section from Ban Khoc to Cua Sap and Yen Phong to the dam. Landslides lakeshore average level includes the following sections: from town It Ong to the Ta Bu, from Chieng Hoa until Ban Khoc and from Ba Sen to Yen Phong. Weak levels include segments: from Ta Bu to Chieng Hoa and Suoi Lua to Ba Sen.

Evolution of Hoa Binh reservoir sedimentation are classified into 3 sections with diferent levels. Level is critical for the passage from Ban Trang to Ban Khoc, accounting for 5.78\% amount of alluvium. Strong level of about passage from Ban Khoc to Suoi Lua, accounting for $77.9 \%$ volume of alluvium. The average level of the period from Suoi Lua to the dam, the volume of alluvium $16.3 \%$. After more than 20 years of Peace reservoirs in operation and exploitation (1989-2013), sediment deposition has lost $37 \%$ of dead storage, in the middle lake was filling both the useful capacity.

Hoa Binh hydropower reservoir fairly strong, with different levels in space. Clips lakes fluctuate strongly from Cua Sap to Suoi Lua; Strong: from Yen Phong to the dam; Average: from Ban Khoc to Cua Sap and from Ba Sel to Yen Phong; weak: from Son La dam to It Ong, from Hin Pha to Ban Khoc and from Suoi Lua to Ba Sel; Very weak: from It Ong to Hin Pha.

(C2016 Vietnam Academy of Science and Technology

\section{Mở đầu}

Hồ thủy điện Hòa Bình có vị trí địa lý từ $20^{\circ} 36^{\prime} 51^{\prime \prime}$ đến $21^{\circ} 42^{\prime} 57^{\prime \prime}$ vĩ độ Bắc và $103^{\circ} 45^{\prime} 34^{\prime \prime}$ đến $105^{\circ} 25^{\prime} 43$ ” kinh độ Đông, thuộc địa phận các tỉnh Hòa Bình và Sơn La của vùng Tây Bắc nước ta (hình 1).

Đây là hồ chứa dạng sông dài, hẹp và sâu, nằm

*Tác giả liên hệ, Email: buivanthom@gmail.com trên dòng sông Đà. Từ khi hồ thủy điện đi vào hoạt động đã làm thay đổi sâu sắc chế độ thủy văn, thủy lực của dòng sông; làm biến động trạng thái môi trường trong hồ. Quá trình biến động hồ diễn ra cùng đồng thời với các quá trình địa chất động lực trong hồ phát triển: trượt lở bờ hồ và bồi lắng lòng hồ. Đặc biệt, từ khi hồ thủy điện Sơn $\mathrm{La}$ đi vào hoạt động, các quá trình này lại có sự thay đổi đáng kể. Những biến động này đã tác động tiêu cực đến sự tồn tại cũng như sử dụng công trình thủy điện vào mục đích kinh tế dân sinh. 


\section{B.V. Thơm và nnk/Tạp chí Các Khoa học về Trái Đất, Tập 38 (2016)}

Kể từ khi hồ thủy điện Hòa Bình đi vào hoạt động, một số công trình đã đề cập đến đặc điểm biến động hồ theo những khía cạnh khác nhau. Công trình của Trần Trọng Huệ và nnk, 2000 đã nghiên cứu xác lập hiện trạng xói lở mép hồ; Nguyễn Kiên Dũng, 2002 đã sử dụng mô hình Hec-Ras tính toán tốc độ bồi lắng lòng hồ trên cơ sở kết quả đo đạc các mặt cắt địa hình lòng hồ. Như vậy, cho đến nay chưa có công trình nào đánh giá tổng hợp biến động sườn hồ Hòa Bình bao gồm các quá trình trượt lở bờ hồ và bồi lắng lòng hồ. Đề tài cấp Nhà nước mang mã số VT/UD-03/1315 đã triển khai nghiên cứu quá trình trượt lở bờ hồ và bồi lắng lòng hồ thủy điện Hòa Bình. Kết quả nghiên cứu của đề tài về 2 quá trình này là cơ sở tài liệu quan trọng cho nghiên cứu xây dựng bản đồ mức độ trượt lở bờ (TLBH) và bồi lắng lòng hồ (BLLH) Hòa Bình.

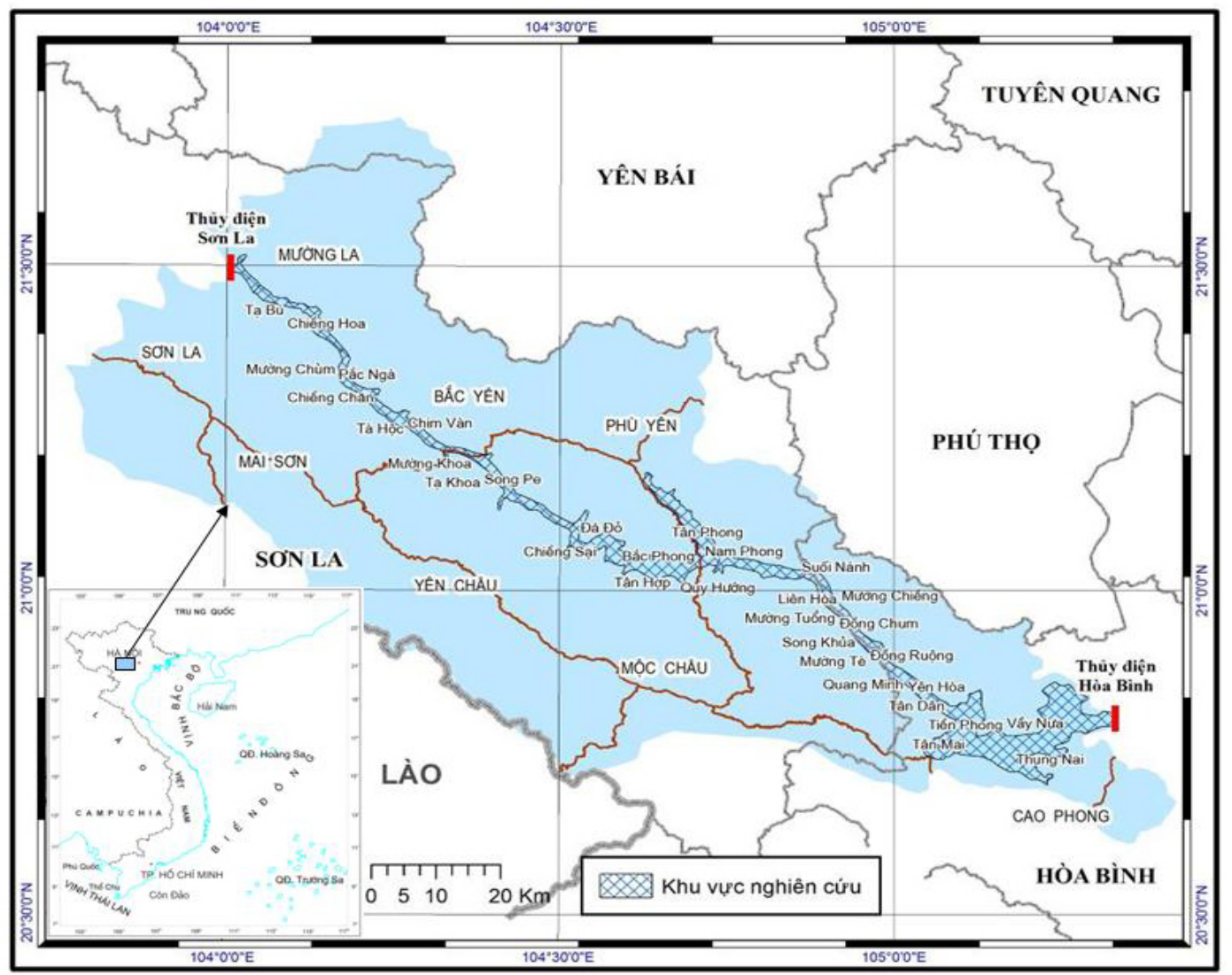

Hình 1. Bản đồ vị trí khu vực nghiên cứu

Xuất phát từ những đòi hỏi của thực tiễn là khai thác sử dụng hồ thủy điện Hòa Bình lâu dài phục vụ phát triển kinh tế-xã hội (KT-XH), công trình này trình bày những kết quả mới về tình trạng trượt lở bờ và bồi lắng lòng hồ Hòa Bình.

\section{Cơ sở tài liệu và phương pháp nghiên cứu}

\subsection{Co' sở tài liệu}

Các tài liệu nghiên cứu đánh giá mức độ TLBH và $B L L H$ rất đa dạng và phong phú, bao gồm các tài liệu của các công trình trước đây đã đề cập và các tài liệu có được khi triển khai thực hiện đề tài VT/UD-03/13-15 trong những năm 2013-2015.

- Các ảnh vệ tinh VNREDSat-1 phân giải 2,5$10 \mathrm{~m}$ chụp vào các năm 2013 và 2014, SPOT-5 phân giải $2,5-10 \mathrm{~m}$ chụp vào năm 2012 và 2013 , Landsat-8 phân giải 10-30m chụp vào năm 2010 . 
Tạp chí Các Khoa học về Trái Đất, 38 (1), 131-142

- Tài liệu thu thập từ các công trình của Trần Trọng Huệ và nnk, 2003, Nguyễn Trọng Yêm và nnk, 2006 và Đào Văn Thịnh và nnk, 2005. Tài liệu đo đạc và tính toán bồi lắng lòng hồ thu thập trong công trình của Nguyễn Kiên Dũng (2002).

- Tài liệu khảo sát thực địa, xác định các khối trượt dọc bờ hồ vào các năm 2014 và 2015; tài liệu đo đạc, tính toán bồi lắng từ các mặt cắt địa hình vào năm 2013 ở hồ Hòa Bình khi thực hiện đề tài VT/UD-03/13-15 do Phạm Quang Sơn làm chủ nhiệm. Toàn bộ các tài liệu, số liệu được thể hiện trên biểu bảng, bản đồ và mặt cắt.

\subsection{Phwong pháp nghiên cúu}

\subsubsection{Phân tích ảnh viễn thám}

Những khối trượt lở diễn ra dọc bờ hồ được ghi nhận và thể hiện rất rõ trên ảnh viễn thám phân giải cao. Các thông tin cần thiết chiết xuất từ ảnh vệ tinh là hiện trạng diễn biến của quá trình TLBH và yếu tố phát sinh chúng. Thông qua các dấu hiệu ảnh: trực tiếp (tôn ảnh, hoa văn, tổ hợp màu,...) và gián tiếp (những yếu tố lớp phủ, địa hình, địa mạo và thành phần vật chất trên bề mặt,...) cho phép xác lập vị trí, quy mô các khối trượt, các yếu tố tác động phát sinh trượt lở (Nguyễn Tứ Dần và nnk, 2007, Richard, Jon A., 1986, Sabins F.F., 1978). Ví dụ như, các khối trượt, dòng lũ bùn đá (LBĐ) thể hiện rõ nét trên ảnh là những tôn ảnh, hoa văn, tổ hợp màu, độ sáng tối,... khác hẳn với xung quanh. Tập thể tác giả đã sử dụng các ảnh viễn thám phân giải cao (VNREDSat-1, SPOT-5 và Landsat-8) để giải đoán nhận dạng các khối trượt lở bờ hồ, dòng LBĐ và các yếu tố phát sinh trượt lở bờ hồ. Kết quả phân tích viễn thám kết hợp với khảo sát thực địa cho phép xác lập các khối TLBH và dòng $\mathrm{LBĐ}$ ở sườn hồ Hòa Bình (hình 2, 3).
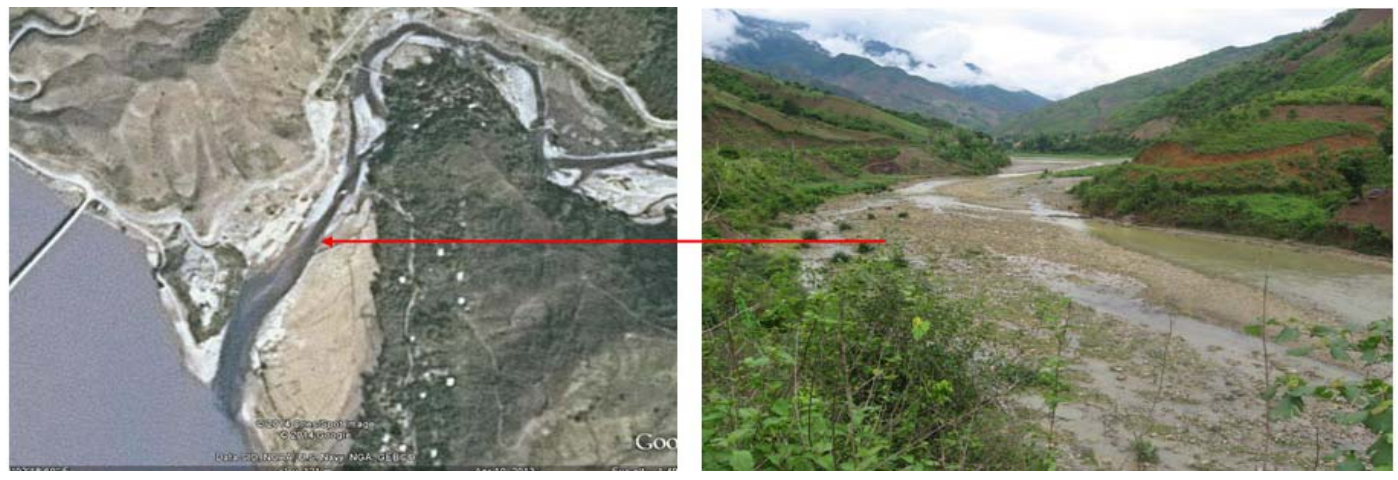

Hình 2. Ảnh trượt lở kèm lũ bùn đá tại Nậm Chiến trên ảnh Landsat và chụp mặt đất (ảnh: Phạm Văn Hùng)
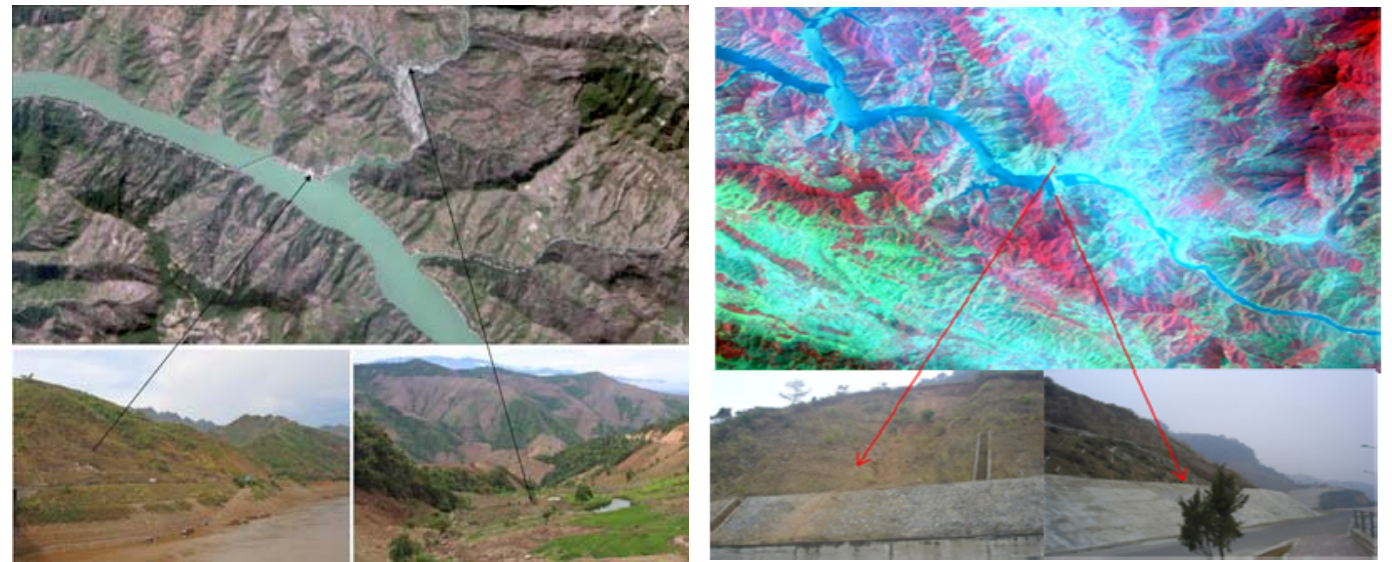

Hình 3. Ảnh trượt lở và lũ bùn đá tại Tạ Khoa (trái), đập thủy điện Sơn La (phải) trên ảnh VNREDSat-1 và chụp mặt đất (ảnh: Phạm Văn Hùng) 


\section{B.V. Thơm và nnk/Tạp chí Các Khoa học về Trái Đất, Tập 38 (2016)}

\subsubsection{Khảo sát thực địa, đo đạc thu thập tài liệu}

Các tài liệu thống kê, đo đạc hàng năm về TLBH và $B L L H$ ở các ngành, địa phương là cơ sở để phân tích xác lập quy mô, tần suất xuất hiện và mức độ phát triển TLBH và BLLH. Điều tra, khảo sát chi tiết ngoài thực địa cho phép thu thập, tổng hợp các số liệu về hiện trạng và những thiệt hại do TLBH và BLLH gây ra (Nguyễn Tứ Dần và nnk, 2007; Nguyễn Kiên Dũng, 2002; Trần Trọng Huệ và nnk, 2000). Ngoài thực địa, các khối trượt được đo vẽ chi tiết, xác định các đặc trưng về vị trí, kích thước, phân loại, thời gian xuất hiện. Quy mô khối trượt được phân ra các bậc khác nhau: rất lớn $\left(>10.000 \mathrm{~m}^{3}\right)$, lớn $\left(1.000-10.000 \mathrm{~m}^{3}\right)$, trung bình $\left(100-1.000 \mathrm{~m}^{3}\right)$, nhỏ $\left(<100 \mathrm{~m}^{3}\right)$ (Nguyễn Trọng Yêm và nnk, 2006). Đó là những tài liệu quan trọng làm cơ sở để đánh giá mức độ TLBH.

Trong những năm qua, Viện Khoa học Khí tượng Thủy văn và Môi trường đã phối hợp với Công ty thủy điện Hòa Bình tiến hành xây dựng hệ thống mặt cắt để đo đạc và tính toán lượng bồi lắng cát bùn của hồ bằng phương pháp so sánh thể tích với 39 mặt cắt ngang từ cửa đập đến Chim Vàn (huyện Mai Sơn). Đến năm 1990 khi mực nước dâng đến cao trình bình thường, hệ thống mặt cắt được xây dựng hoàn chỉnh với 64 mặt cắt từ đập lên đến Bản Trang (huyện Mường La). Thời gian khảo sát địa hình lòng hồ là tháng XII hàng năm, lúc dòng chảy nước và bùn cát đến hồ là nhỏ nhất, lòng hồ tương đối ổn định đảm bảo tính đồng nhất của bộ số liệu đo đạc. Để xác định lượng bùn cát bồi lắng hồ Hòa Bình bằng phương pháp so sánh thể tích, dùng phần mềm TOPO nội suy đường đồng mức ở khu vực mặt cắt theo mô hình mặt cắt. Sau đó dùng lệnh vẽ mặt cắt chính qua 2 điểm TA và $\mathrm{PA}$. Chương trình sẽ tự động vẽ mặt cắt chính có điểm đầu là $\mathrm{TA}$ và điểm cuối là $\mathrm{PA}$ với khoảng cách giữa 2 điểm đo sâu là $10-15 \mathrm{~m}$. Cuối cùng là sử dụng mô hình Hec-Ras để tính ra thể tích. Về nguyên tắc, nếu các mặt cắt ngang bố trí càng dày thì kết quả tính toán thể tích lòng hồ và lượng bùn cát bồi lắng càng chính xác. Úng với cao trình $115 \mathrm{~m}$, hồ Hòa Bình rộng 19.730ha. Thực tế có 64 mặt cắt bố trí trên lòng chính, đáp ứng hơn một nửa số mặt cắt tối thiểu tính theo lý thuyết, trung bình khoảng $3 \mathrm{~km} / 1$ mặt cắt, có nơi lên tới hơn $10 \mathrm{~km}$, các phụ lưu lớn của hồ như Hiền Lương, suối Rút, suối Tốc.... chưa xây dựng mặt cắt khống chế nên kết quả tính toán chỉ đạt được độ chính xác nhất định (Nguyễn Kiến Dũng, 2002).

\subsection{Phuơng pháp xây dựng bản đồ}

Phương pháp xây dựng bản đồ đã được sử dụng để đánh giá mức độ TLBH và BLLH. Trên cơ sở phân tích hiện trạng của các quá trình TLBH và $B L L H$ cho phép xây dựng các bản đồ mức độ TLBH và $B L L H$. Bản đồ mức độ TLBH được xây dựng trên cơ sở mật độ khối trượt (khối $/ \mathrm{km})$ và được phân thành 3 cấp: mạnh, trung bình và yếu. Bản đồ mức độ bối lắng lòng hồ thể hiện lượng trầm tích bồi lắng theo không gian và phân thành 3 cấp: mạnh, trung bình và yếu trên cơ sở phân tích 56 mặt cắt tính toán bồi lắng trong hồ Hòa Bình giai đoạn 1990-2013. Bản đồ mức độ TLBH và $B L L H$ hồ Hòa Bình được xây dựng trên cơ sở tích hợp các bản đồ mức độ trượt lở bờ hồ và bồi lắng lòng hồ theo ma trận so sánh cấp độ TLBH và BLLH (bảng 1) (Nguyễn Trọng Yêm và nnk, 2006). Bản đồ thể hiện ở 5 cấp độ khác nhau: rất mạnh, mạnh, trung bình, yếu và rất yếu.

Bảng 1. Ma trận so sánh cấp độ trượt lở bờ hồ và bối lắng lòng hồ

\begin{tabular}{|c|c|c|c|c|}
\hline & \multicolumn{4}{|c|}{ Bồi lắng lòng hồ } \\
\hline : & & Mạnh & Trung bình & Yếu \\
\hline 0 & Mạnh & Rất mạnh & Mạnh & Trung bình \\
\hline ț. & Trung bình & Mạnh & Trung bình & Yếu \\
\hline$\Xi$ & Yếu & Trung bình & Yếu & Rất Yếu \\
\hline
\end{tabular}

\section{Kết quả và thảo luận}

\subsection{Truọt lở bò̀ hồ}

Trên cơ sở tổng hợp các tài liệu phân tích giải đoán ảnh viễn thám phân giải cao và kết quả khảo sát, thu thập tài liệu (Trần Trọng Huệ và nnk, 2000, Đào Văn Thịnh và nnk, 2005) cho phép xây dựng bản đồ hiện trạng trượt lở bờ hồ thủy điện Hòa Bình (hình 4). 
Tạp chí Các Khoa học về Trái Đất, 38 (1), 131-142

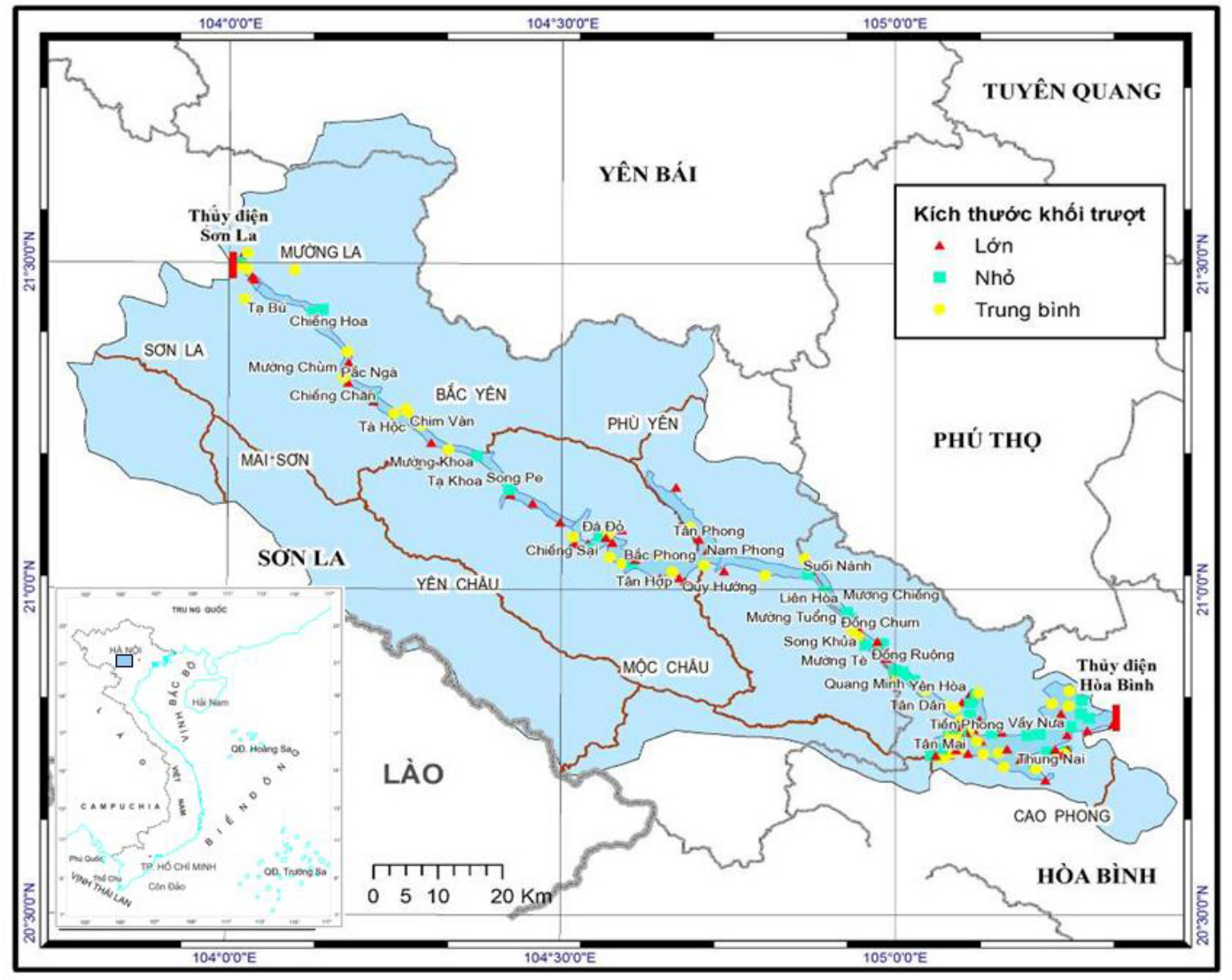

Hình 4. Bản đồ hiện trạng trượt lở bờ hồ Hòa Bình

Trên bờ hồ Hòa Bình đã xác lập được 161 khối trượt lớn nhỏ phân bố tập trung ở một số đoạn. Các đoạn có mật độ trượt lở lớn (4-5 khối $/ \mathrm{km})$ : từ Cửa Sập đến Suối Lúa và từ Yên Phong đến đập. Các đoạn có mật độ trượt lở trung bình (2-3 khôi $/ \mathrm{km})$ : từ đập Sơn La đến Ít Ong, từ Hin Phá (Chiềng Hoa) đến Bản Khộc và từ $\mathrm{Ba}$ Sel đến Yên Phong. Các đoạn có mật độ trượt lở yếu (<2 khối $/ \mathrm{km})$ : từ Ít Ong đến Hin Phá, từ Bản Khộc đến Cửa Sập và từ Suối Lúa đến $\mathrm{Ba}$ Sel.

Đoạn từ $\mathrm{Pa}$ Vinh đến Bản Lừm, lòng hồ hẹp, vách hồ dốc, phần lớn các khối trượt lở thuộc loại nhỏ. Đoạn từ Bản Lừm đến Bản Chanh phân bố các khối trượt nhỏ đến trung bình, tập trung ở các khu vực Tạ Hộc, Bản Ngà, Bản Chao, Tạ Khoa. Đoạn từ Bản Chanh đến đập, trượt lở xảy ra phức tạp. Từ Bản Chanh đến Bãi Tre, có lòng hồ hẹp, độ dốc sườn lớn, trượt lở xảy ra mạnh mẽ, phân bố hàng chục khối trượt ở Bản Chanh, Bãi Vàng, Bãi
Sại. Trên đoạn từ Bãi Vàng đến Bãi Tre, lòng hồ rộng chạy đổi hướng liên tục, phân bố hàng chục khối trượt lở thuộc loại nhỏ đến trung bình. Đoạn từ Bãi Tre đến Bản Mực, lòng hồ mở rộng dần, đặc biệt là từ Vạn Yên, nơi có suối Tấc chảy ra, lòng hồ được mở rộng đáng kể. Trên đoạn từ Bãi Tre đến Vạn Yên phân bố hàng chục khối trượt lớn nhỏ, trong đó kể đến 2 khối trượt lở lớn tại Vạn Yên, cách bến phà Vạn Yên $800 \mathrm{~m}$ về phía đập. Có thể nói, đây là điểm trượt lở điển hình ở khu vực hồ Hòa Bình. Dọc Suối Tấc từ Phù Yên đến Vạn Yên, đặc biệt ở nơi gần cửa suối, phân bố nhiều điểm trượt lở. Trên đoạn từ Vạn Yên đến Đá Mài, tại ngã ba Suối Giằng và hai bên bờ cách Suối Lúa gần $1 \mathrm{~km}$ về phía hạ lưu quan sát thấy nhiều điểm trượt lở nhỏ. Hiện tượng trượt lở tương tự còn phổ biến trên đoạn bờ dài $1 \mathrm{~km}$ ở khu vực Đá Mài. Trên Đoạn từ Đá Mài đến Bến Khủa, lòng hồ hẹp, vách đá vôi dốc đứng, xuất hiện khối lở đá. Đoạn từ Bến 


\section{B.V. Thơm và nnk/Tạp chí Các Khoa học về Trái Đất, Tập 38 (2016)}

Khủa đến Sinh Vinh, phân bố khối 4 khối trượt lở. Đoạn từ Sinh Vinh đến Hạt phân bố 2 khối trượt trung bình.Đoạn từ Bản Mực đến đập, phân bố hàng chục khối trượt lở nhỏ.

Trong năm 1986-1987, khi mực nước hồ ở cao trình $45 \mathrm{~m}$, trong phạm vi đới dao động mực nước đã xảy ra hiện tượng trượt lở bờ. Ở khu vực Làng Gia-Suối Rút, từ Bản Mực về đến đập phân bố hàng chục khối trượt lớn nhỏ, trong đó có 6 khối trượt lớn. Trên đoạn bờ phải ở Làng Gia, dài khoảng $500 \mathrm{~m}$, đoạn bờ trái sông Đà tại Làng Trương dài $1.200 \mathrm{~m}$, đoạn từ Suối Vôi đến đập, các bờ Suối Rút, Ngòi Hoa, Suối Chiêu và Hiền Lương phân bố hàng chục khối trượt. Vào năm 1989 mực nước hồ dao động từ cao trình $84 \mathrm{~m}$ đến $89 \mathrm{~m}$, từ Bản Mực đến Bản Vàn (Chiêm Vàn) phân bố 16 khối trượt lở lớn nhỏ, trong đó có 2 khối trượt lớn ở Vạn Yên (hình 5,6) và Bản Mực (hình 7). Đầu năm 1991 mực nước ở cao trình $115,4 \mathrm{~m}$, trượt lở đất xảy ra ở Làng Ngòi, Tà Phù, Nánh, Suối Lúa. Từ đập đến Bản Vàn phân bố 8 khối trượt ở mép nước. Từ đập đến Bản Vàn phân bố gần 100 khối trượt lở. Năm 1992, các khu vực phát triển trượt lở mạnh là các đoạn: Hạt-Kế, Suối Lúa-Vạn Yên, Bản Mong-Bản Tranh, Bản Tranh-Tạ Khoa (hình 8).
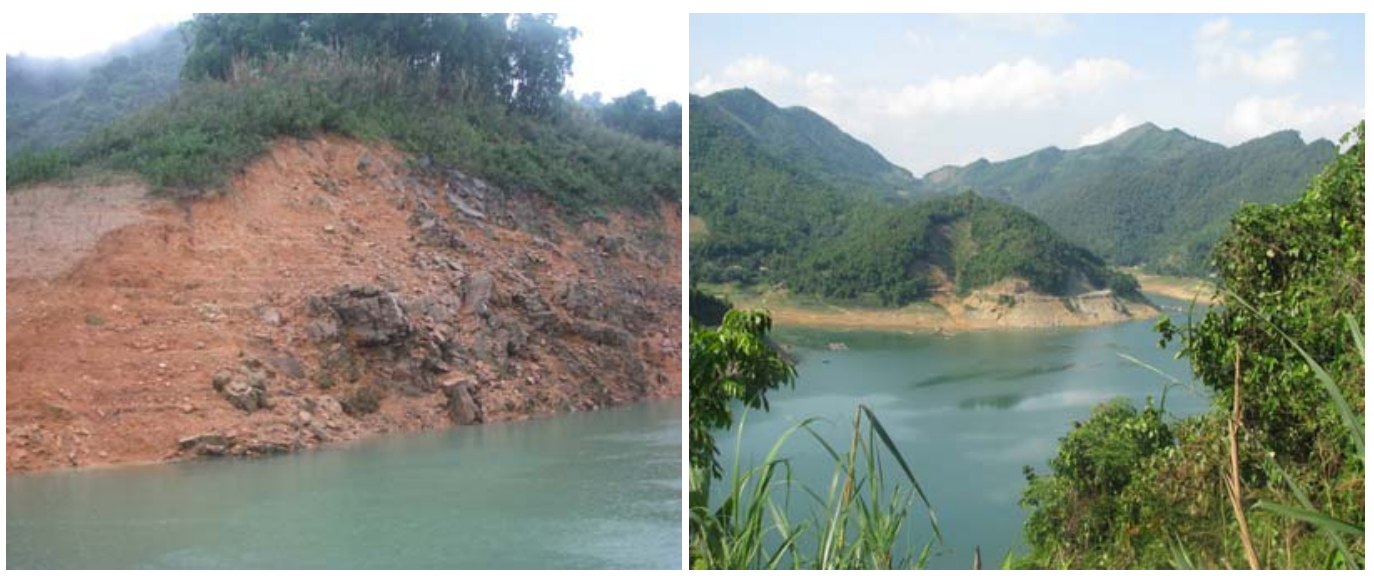

Hình 5. Trượt lở bờ hồ tại Vầy Nưa và Hiền Lương (Ảnh: Phạm Văn Hùng)
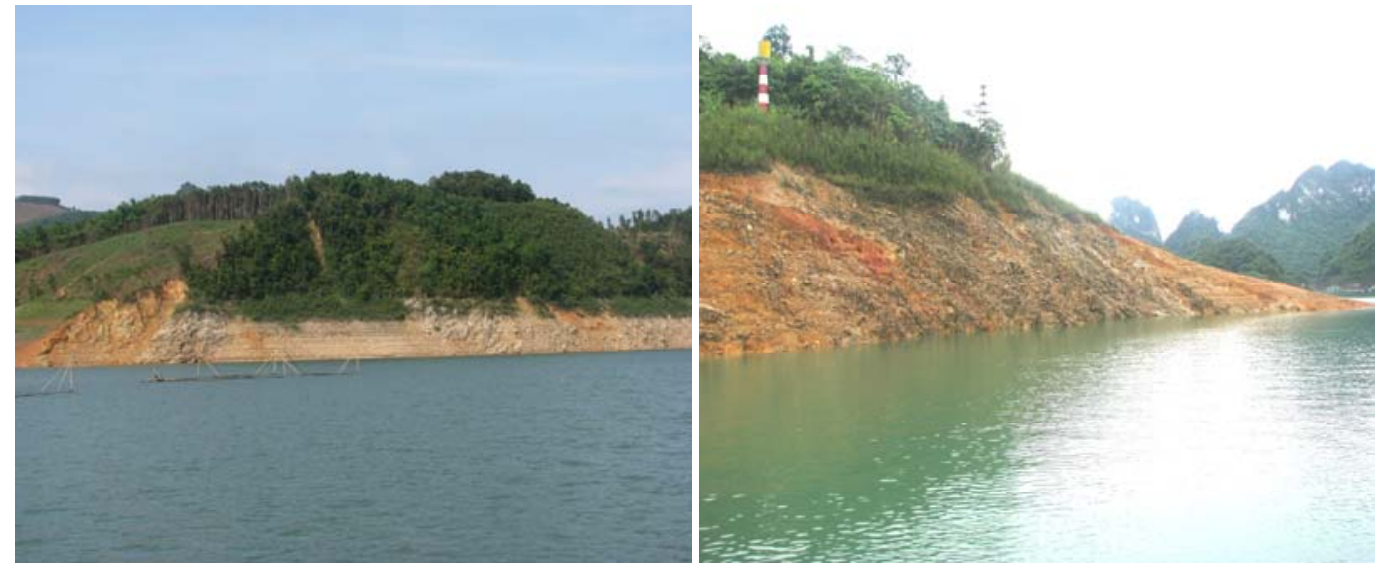

Hình 6. Ảnh trượt lở bờ hồ ở Tân Mai và Chợ Bờ (Ảnh Phạm Văn Hùng) 
Tạp chí Các Khoa học về Trái Đất, 38 (1), 131-142
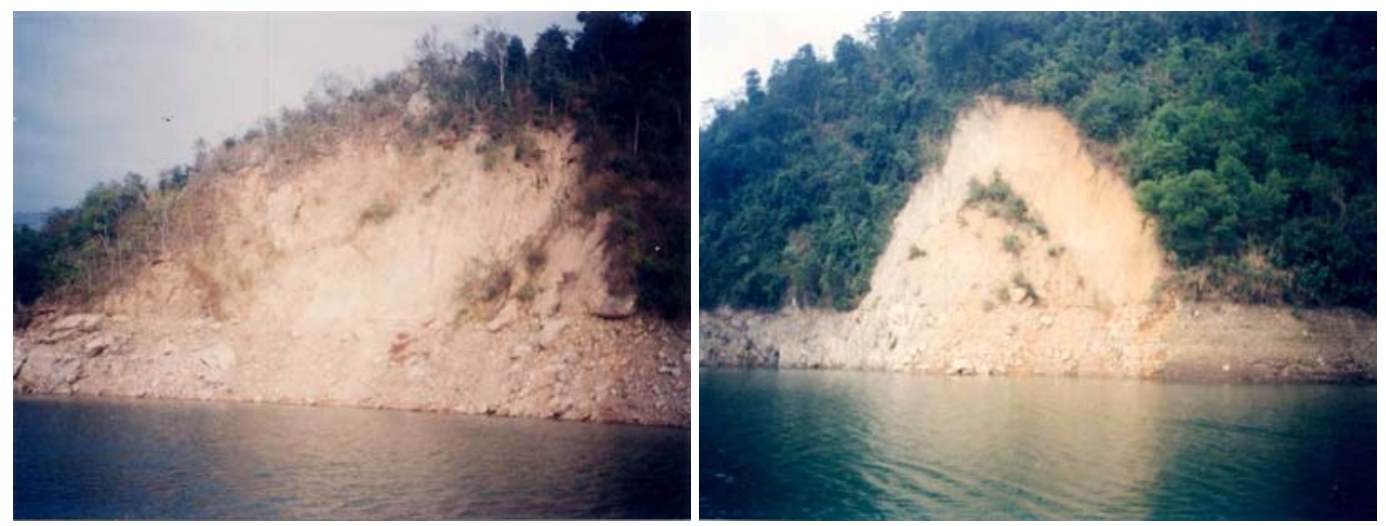

Hình 7. Ảnh trượt lở bờ hồ tại Vạn Yên và Bản Mực (Ảnh Phạm Văn Hùng)
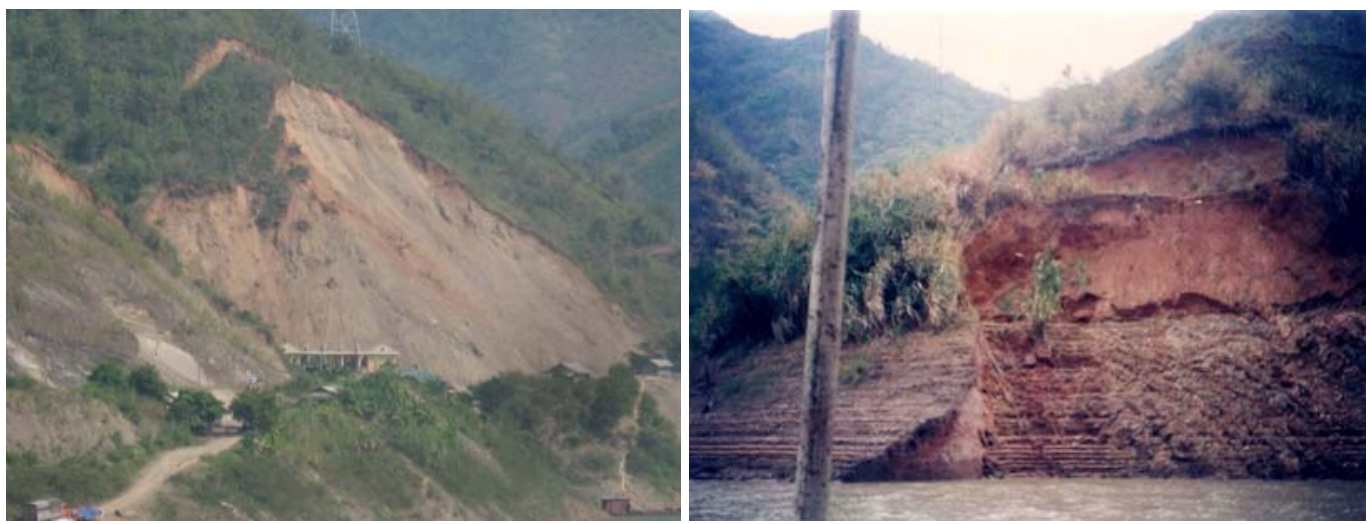

Hình 8. Ảnh trượt lở bờ hồ ở đầu cầu Tạ Khoa (ảnh Phạm Văn Hùng)

Những đoạn bờ hồ đã bị trượt lở vẫn tiếp tục trượt. Trong những năm 1998-2002, từ Pa Vinh đến đập đã xác lập được 65 khối trượt lở. Từ năm 2013 đến nay, kết quả khảo sát thực địa và phân tích ảnh viễn thám phân giải cao cho thấy, diễn biến trượt lở xảy ra như các năm từ 1998-2002. Tuy nhiên, do nhiều lần mực nước hồ biến động, vật liệu tích đọng ngay dưới sườn bờ ngầm do trượt lở từ những năm trước, nay lại tiếp tục trượt.

\subsection{Bồi lắng lòng hồ}

Công trình thủy điện được bắt đầu xây dựng từ năm 1979 và hoàn thành toàn bộ vào tháng 12/1994. Ngay trong giai đoạn đầu xây dựng mạnh mẽ nhất (1987-1989), chế độ thủy văn của sông Đà đã có những thay đổi nhất định. Tuy nhiên, những thay đổi rõ rệt được ghi nhận kể từ năm 1990 khi hồ tích nước và điều tiết (Nguyễn Kiên Dũng, 2002). Sau 24 năm hồ tích nước đến cao trình bình thường, tổng lượng nước về hồ là $1.319,9$ tỷ m³ trung bình 55,5 tỷ $\mathrm{m}^{3} / \mathrm{năm}$. Với lượng nước khổng lồ này đã tạo ra tổng lượng cát bùn bồi lắng lòng hồ là $1.387,1$ triệu $\mathrm{m}^{3}$, trung bình 57,8 triệu $\mathrm{m}^{3} / \mathrm{năm}$. Trên cơ sở tổng hợp tài liệu đo đạc, tính toán dọc hồ cho thấy, hiện trạng bồi lắng lòng hồ Hòa Bình diễn ra rất phức tạp (hình 9).

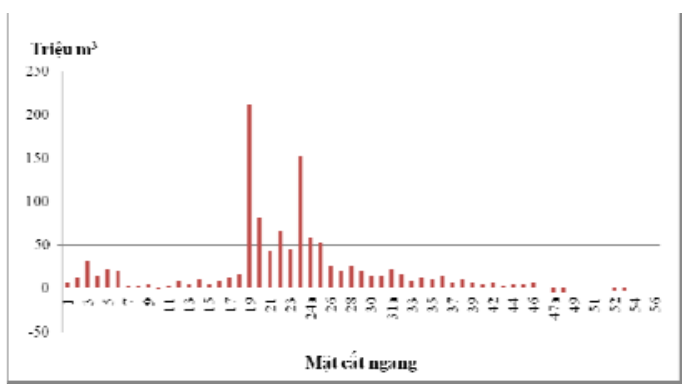

Hình 9. Biểu đồ phân bố lượng bồi lắng theo không gian dọc hồ đến năm 2013 


\section{B.V. Thơm và nnk/Tạp chí Các Khoa học về Trái Đất, Tập 38 (2016)}

Sau thời gian dài hồ tích nước điều tiết, bãi bồi được hình thành rất rõ tại khu vực trung lưu của hồ, đỉnh của bãi bồi di chuyển về khu vực Suối Lúa - Nà Giang, cách đập $83,3 \mathrm{~km}$; đuôi trên của bãi bồi tại Bản Khộc, huyện Bắc Yên, Sơn La, cách đập $139,3 \mathrm{~km}$. Như vậy bãi bồi có chiều dài tương đương khoảng $56,1 \mathrm{~km}$. Với sự hình thành của bãi bồi ở khu vực trung lưu của hồ, mức độ bồi lắng chia thành 3 đoạn: thượng lưu (đập Sơn La đến Bản Khộc, trung lưu (từ Bản Khộc đến Nà Giang) và hạ lưu (từ Nà Giang đến đập). Đoạn thượng lưu hồ có chiều dài $53 \mathrm{~km}$, địa hình lòng sông gần giống với sông thiên nhiên (khi chưa có hồ): cao trình đáy sông lớn, dao động 88-114m, độ dốc đáy sông lớn, độ rộng lòng sông nhỏ, dao động 200-350m (ứng với cao trình mực nước $120 \mathrm{~m}$ ) nên lượng bùn cát giữ lại ở khu vực này không nhiều. Trong suốt thời kỳ hoạt động của hồ chứa, tổng lượng bùn cát lắng đọng ở đây là 80,12 triệu $\mathrm{m}^{3}$, chiếm khoảng $5,78 \%$ tổng lượng bùn cát lắng đọng trong toàn tuyến hồ. Phân đoạn từ Bản Trang về đến Tạ Bú có chiều dài $8,5 \mathrm{~km}$, cao trình đáy sông $101-114 m$, chiều rộng trung bình mặt hồ 200-230 $\mathrm{m}$, lượng bùn cát giữ lại trong hồ chiếm $0,65 \%$ tổng lượng bùn cát trong toàn tuyến hồ (tương đương $9.016 .215 \mathrm{~m}^{3}$ ). Phân đoạn từ Tạ Bú về đến Bản Khộc dài $50 \mathrm{~km}$, cao trình đáy sông $88-101 \mathrm{~m}$, độ rộng trung bình mặt hồ khoảng $320 \mathrm{~m}$, lượng bùn cát bồi lắng chiếm $5,13 \%$ tổng lượng bùn cát toàn hồ (tương đương $71.158 .743 \mathrm{~m}^{3}$ ). Đoạn trung lưu dài $56,1 \mathrm{~km}$, cao trình đáy sông $60-88 \mathrm{~m}$, độ rộng trung bình khoảng $490 \mathrm{~m}$, lượng phù sa bồi lắng lớn nhất trong toàn hồ, chiếm $77,9 \%$ tổng lượng bùn cát bồi lắng trong hồ (tương đương $1.080,48$ triệu $\mathrm{m}^{3}$ ). Do vậy, ở đoạn này hình thành bãi bồi với chiều dài $56 \mathrm{~km}$. Đoạn hạ lưu dài $83,3 \mathrm{~km}$, độ cao đáy sông thấp $15-60 \mathrm{~m}$, độ dốc đáy sông nhỏ, độ rộng trung bình mặt hồ $930 \mathrm{~m}$. Đoạn này chịu ảnh hưởng trực tiếp của việc điều tiết hồ nên lượng bùn cát lắng đọng tại đây nhỏ, tính đến thời điểm 2013 chiếm khoảng 16,3\% tổng lượng bùn cát toàn hồ (tương đương 22,657 triệu $\mathrm{m}^{3}$ ) (Nguyễn Kiên Dũng, 2002).

Như vậy, sau hơn 20 năm hồ chứa Hòa Bình đi vào vận hành và khai thác tài nguyên nước, tổng lượng cát bùn được giữ lại trong hồ là 1.423,11 triệu $\mathrm{m}^{3}$ (1989-2013). Với khối lượng cát bùn khổng lồ đã bồi lấp mất $37 \%$ dung tích chết, ở khu vực bãi bồi (trung lưu hồ) đã bồi lấp cả phần dung tích hữu ích.

\subsection{Mức độ truọt lở bò̀ và bồi lắng lòng hồ}

\subsubsection{Xây dụ̂ng bản đồ}

Trên cơ sở phân tích hiện trạng TLBH (mật độ, quy mô và tần suất xuất hiện trượt lở) cho phép xây dựng bản đồ mức độ trượt lở bờ hồ Hòa Bình. Bản đồ mức độ trượt lở bờ hồ thể hiện 3 cấp độ khác nhau: Mạnh ( $>6$ khối $/ \mathrm{km})$, Trung bình (3-6 khối $/ \mathrm{km}$ ) và Yếu ( $<3$ khối $/ \mathrm{km}$ ) (hình 10$)$. Phân tích bản đồ mức độ trượt lở bờ hồ Hòa Bình cho thấy, quá trình trượt lở bờ hồ diễn ra khá mạnh mẽ với các cấp độ khác nhau ở những đoạn bờ khác nhau. Đoạn từ thị trấn Ít Ong đến xã Tạ Bú (huyện Mường La) dài $6 \mathrm{~km}$, nằm cạnh cửa xả của thủy điện Sơn La, lòng hồ tương đối hẹp nhưng độ dốc lớn, trượt lở bờ hồ diễn ra ở mức độ trung bình. Đoạn từ xã Tạ Bú đến xã Chiềng Hoa (huyện Mường La) dài $18 \mathrm{~km}$, chiều rộng lòng hồ hẹp, độ dốc đáy sông lớn, trượt lở bờ hồ ở mức độ yếu. Đoạn từ xã Chiềng Hoa đến bản Khộc (xã Mường Khoa, huyện Bắc Yên) dài $24 \mathrm{~km}$, lòng hồ mở rộng, độ dốc sườn lớn, trượt lở bờ hồ ở mức độ trung bình. Đoạn từ bản Khộc đến bản Cửa Sập (xã Đá Đỏ, huyện Phù Yên) dài $25 \mathrm{~km}$, lòng hồ mở rộng, độ dốc sườn nhỏ, trượt lở bờ bờ hồ ở mức độ yếu. Đoạn từ bản Cửa Sập đến Suối Lúa dài $38 \mathrm{~km}$, lòng hồ mở rộng, cao trình đáy sông nâng cao, trượt lở bờ hồ mạnh. Đoạn từ Suối Lúa đến $\mathrm{Ba}$ Sen (xã Mường Chiềng, huyện Đà Bắc) dài $14 \mathrm{~km}$ lòng hồ hẹp, độ dốc sườn không cao, trượt lở bờ hồ yếu. Đoạn từ $\mathrm{Ba}$ Sen đến Yên Phong (xã Yên Hòa, huyện Đà Bắc) dài $32 \mathrm{~km}$, độ dốc sườn trung bình, trượt lở bờ hồ ở mức trung bình. Đoạn từ Yên Phong đến đập dài $30 \mathrm{~km}$, lòng hồ mở rộng, hai bên bờ chủ yếu là đá biến chất bị dập vỡ mạnh, trượt lở bờ hồ diễn ra mạnh.

Trên cơ sở phân tích kết quả tính toán lượng bồi tích của 56 mặt cắt trong hồ đã cho phép xây dựng bản đồ mức độ bối lắng lòng hồ Hòa Bình thể hiện 3 cấp độ khác nhau: Mạnh $(77,9 \%$ lượng bồi tích), Trung bình (16,3\% lượng bồi tích) và Yếu (5,78\% lượng bồi tích trong hồ) (hình 11). Phân tích bản đồ mức độ bồi lắng lòng hồ Hòa Bình cho thấy, 
Tạp chí Các Khoa học về Trái Đất, 38 (1), 131-142

đoạn từ thị trấn Î́t Ong đến bản Khộc (xã Mường Khoa, huyện Bắc Yên) dài $53 \mathrm{~km}$, độ dốc đáy sông lớn, độ rộng lòng sông nhỏ, lượng bùn cát giữ lại ở khu vực này không nhiều, nên mức độ bồi lắng nhỏ. Đoạn từ bản Bản Khộc đến $\mathrm{Ba}$ Sen (xã Mường Chiềng, huyện Đà Bắc) dài $56 \mathrm{~km}$, chiều rộng trung bình hồ lớn, lượng bùn cát bồi lắng lớn nhất, chiếm
$77,9 \%$ tổng lượng bùn cát bồi lắng trong toàn hồ. Đoạn từ bản $\mathrm{Ba}$ Sen đến đập thủy điện Hòa Bình dài 69,3km, độ cao đáy sông thấp, độ dốc đáy sông nhỏ, độ rộng trung bình mặt hồ lớn nhất. Đồng thời tại khu vực này chịu ảnh hưởng trực tiếp của việc điều tiết hồ nên lượng bùn cát lắng đọng tại đây ở mức trung bình.

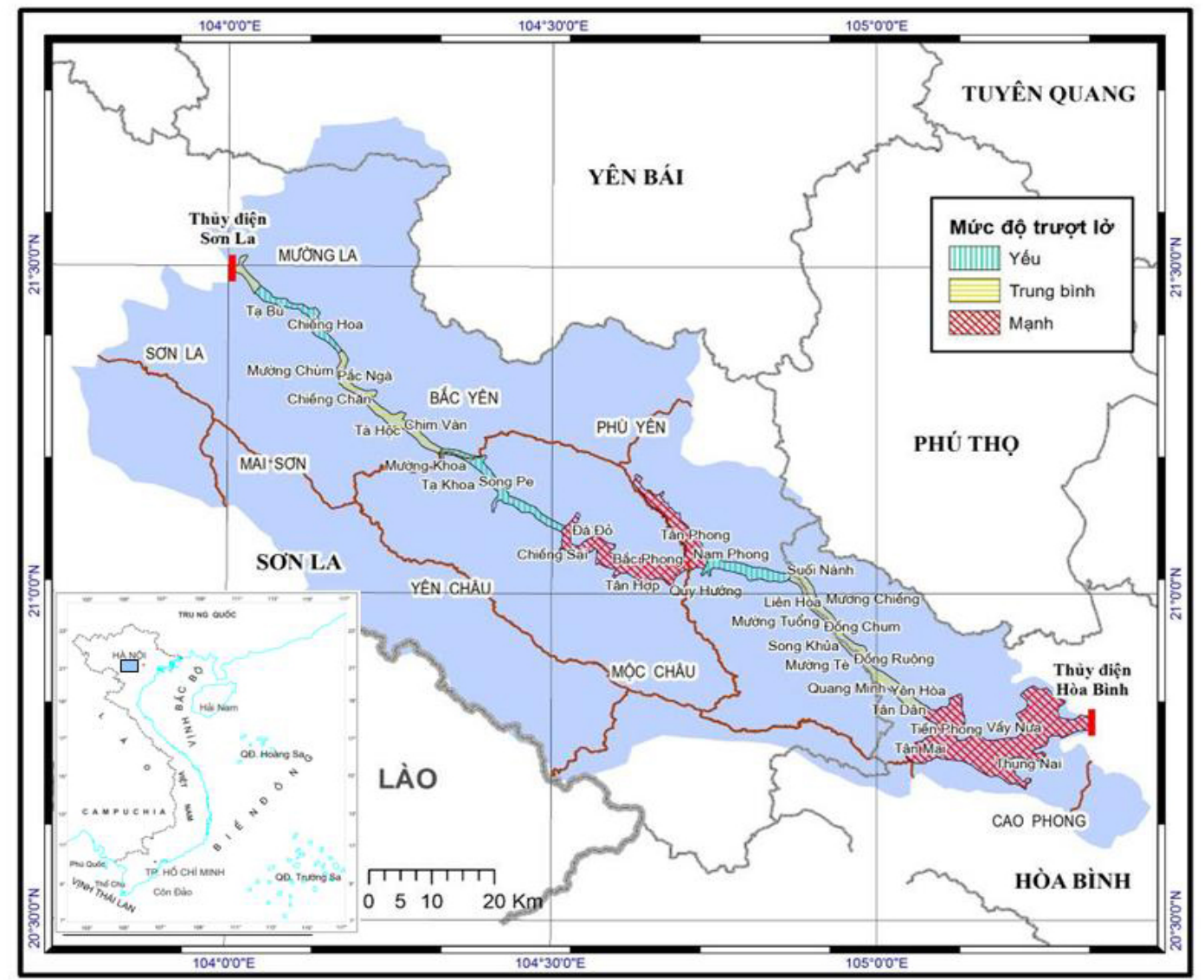

Hình 10. Bản đồ mức độ trượt lở bờ hồ thủy điện Hòa Bình

Theo nguyên tắc xây dựng bản đồ tai biến địa chất (Nguyễn Trọng Yêm và nnk, 2006), bản đồ biến động sườn hồ Hòa Bình được thành lập trên cơ sở tích hợp bản đồ mức độ trượt lở bờ hồ (hình 10) và bản đồ bồi lắng lòng hồ (hình 11) bằng phân tích không gian trong môi trường GIS theo ma trận so sánh cấp độ (bảng 1). Bản đồ biến động sườn hồ Hòa Bình (hình 12) thể hiện ở 5 cấp độ khác nhau: rất mạnh, mạnh, trung bình, yếu và rất yếu.

\subsubsection{Mức độ trươt lở bò̀ và bồi lắng lòng hồ thủy điện Hòa Bình}

Phân tích tổng hợp bản đồ mức độ trượt lở bờ và bồi lắng lòng hồ Hòa Bình cho thấy, hồ Hòa Bình bị trượt lở bờ và bồi lắng lòng hồ thuộc loại trung bình kể từ khi hồ tích nước và đưa vào sử dụng phục vụ phát triển KT-XH ở nước ta. Tuy nhiên, mức độ trượt lở bờ và bồi lắng lòng hồ không giống nhau theo từng đoạn hồ khác nhau. 
B.V. Thơm và nnk/Tạp chí Các Khoa học về Trái Đất, Tập 38 (2016)

Đoạn từ bản Tạ Bú (xã Tạ Bú, huyện Mường La) đến bản Hin Phá (xã Chiềng Hoa, huyện Mường La) dài $18 \mathrm{~km}$, có mức độ trượt lở bờ thấp (mật độ trượt lở thấp <2 khối $/ \mathrm{km}$ ), mức độ bồi lắng lòng hồ thấp (lớp bùn cát bồi lắng lòng hồ tại khu vực này ít, $<6 \%$ tổng lượng bùn cát bồi lắng trong hồ). Như vậy, mức độ trượt lở bờ và bồi lắng lòng hồ của đoạn này là rất thấp.
Đoạn từ thị trấn Ít Ong (huyện Mường La) đến bản Tạ Bú (xã Tạ Bú, huyện Mường La) dài $6 \mathrm{~km}$, có mức độ trượt lở bờ trung bình (mật độ trượt lở trung bình 2-4 khối/km), mức độ bồi lắng lòng hồ thấp (lớp bùn cát bồi lắng lòng hồ tại khu vực này ít, $<6 \%$ tổng lượng bùn cát bồi lắng trong hồ). Như vậy, mức độ trượt lở bờ và bồi lắng lòng hồ của đoạn này là thấp.

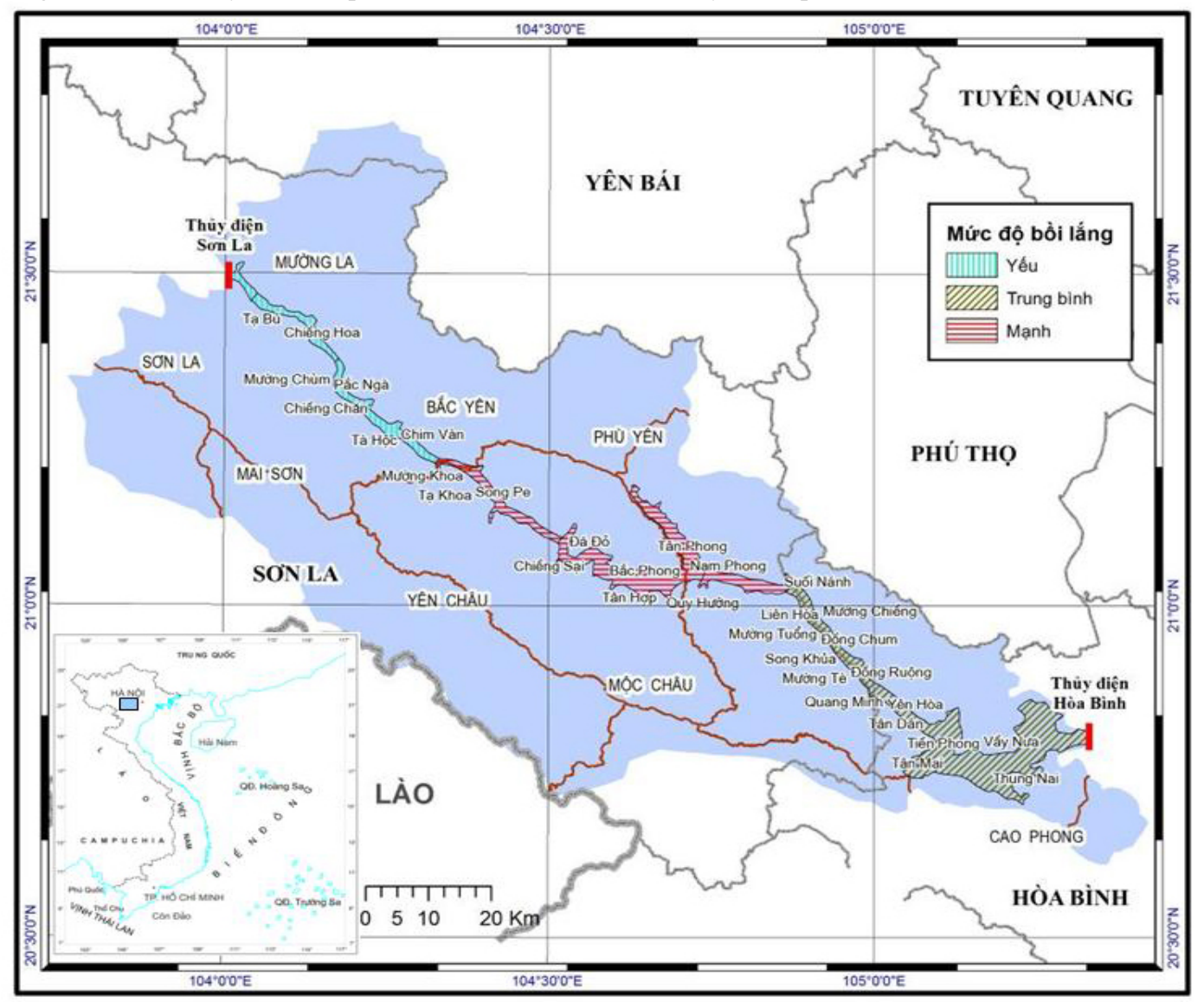

Hình 11. Bản đồ mức độ bồi lắng lòng hồ thủy điện Hòa Bình

Đoạn từ bản Hin Phá (xã Chiềng Hoa, huyện Mường La) đến bản Khộc (xã Mường Khoa, huyện Bắc Yên) dài $24 \mathrm{~km}$, có mức độ trượt lở bờ trung bình (mật độ điểm trượt lở trung bình 2-4 khối $/ \mathrm{km}$ ), mức độ bồi lắng lòng hồ thấp (lớp bùn cát bồi lắng lòng hồ tại khu vực này ít, <6\% lượng bồi lắng trong hồ). Như vậy, mức độ trượt lở bờ và bồi lắng lòng hồ ở mức độ trung bình.
Đoạn từ bản Khộc (xã Mường Khoa, huyện Bắc Yên) đến bản Cửa Sập ( xã Đá Đỏ, huyện Phù Yên) dài $25 \mathrm{~km}$, có mức độ trượt lở bờ thấp (mật độ trượt lở thấp, $<2 \mathrm{khối} / \mathrm{km}$ ), mức độ bồi lắng lòng hồ lớn nhất hồ Hòa Bình, $>78 \%$ lượng bồi tích bồi lắng hồ. Như vậy, mức độ trượt lở bờ và bồi lắng lòng hồ ở mức mạnh.

Đoạn gồm 2 nhánh: từ bản Cửa Sập (xã Đá Đỏ, 
Tạp chí Các Khoa học về Trái Đất, 38 (1), 131-142

huyện Phù Yên) đến suối Lúa (xã Nam Phong, huyện Phù Yên) và từ bản Chợp (xã Tường Thượng, huyện Phù Yên) đến Suối Lúa dài $38 \mathrm{~km}$, có mức độ trượt lở bờ lớn (có mật độ trượt lở lớn,
$>4$ khối $/ \mathrm{km}$ ); mức độ bồi lắng lòng hồ lớn nhất hồ Hòa Bình, $>78 \%$ lượng bồi tích bồi lắng hồ. Như vậy, mức độ trượt lở bờ và bồi lắng lòng hồ ở mức rất mạnh.

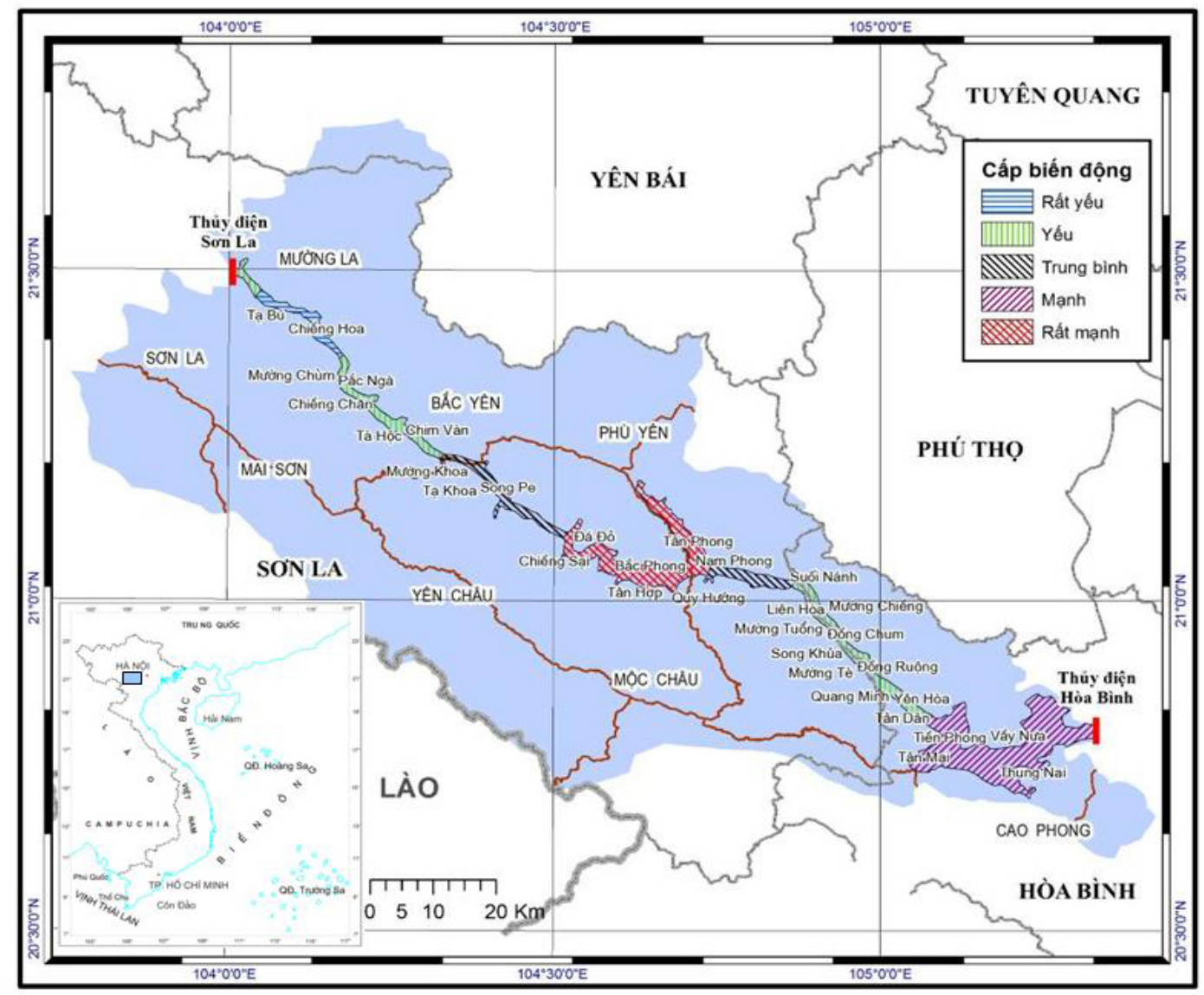

Hình 12. Bản đồ mức độ trượt lở bờ và bồi lắng lòng hồ tổng hợp ở hồ thủy điện Hòa Bình

Đoạn từ suối Lúa (xã Nam Phong, huyện Phù Yên) đến $\mathrm{Ba}$ Sen (xã Mường Chiềng, huyện Đà Bắc) dài $14 \mathrm{~km}$, có mức độ trượt lở bờ thấp (mật độ trượt lở nhỏ <2 khối $/ \mathrm{km}$ ), mức độ bồi lắng lòng hồ trung bình (lớp bùn cát bồi lắng lòng hồ tại khu vực này trung bình, $16 \%$ tổng lượng bùn cát bồi lắng trong hồ). Như vậy, mức độ trượt lở bờ và bồi lắng lòng hồ của đoạn này là yếu.

Đoạn từ $\mathrm{Ba}$ Sen (xã Mường Chiềng, huyện Đà Bắc) đến Yên Phong (xã Yên Hòa, huyện Đà Bắc) dài $32 \mathrm{~km}$, có mức độ trượt lở trung bình (mật độ trượt lở trung bình 2-4 khối/km), mức độ bồi lắng lòng hồ trung bình (lớp bùn cát bồi lắng lòng hồ ở mức trung bình $17 \%$ lượng bồi tích lòng hồ). Như vậy, mức độ trượt lở bờ và bồi lắng lòng hồ của đoạn này là trung bình.

Đoạn từ Yên Phong (xã Yên Hòa, huyện Đà Bắc) đến đập dài $30 \mathrm{~km}$, có mức độ trượt lở rất lớn (mật độ trượt lở lớn $>4$ khối/km), mức độ bồi lắng lòng hồ trung bình (lớp bùn cát bồi lắng lòng hồ ở mức trung bình $16 \%$ lượng bồi tích lòng hồ). Như vậy, mức độ trượt lở bờ và bồi lắng lòng hồ của đoạn này là mạnh. 


\section{B.V. Thơm và nnk/Tạp chí Các Khoa học về Trái Đất, Tập 38 (2016)}

Như vậy, đoạn bờ bị trượt lở bờ và bồi lắng lòng hồ mạnh nhất thuộc về trung lưu hồ, từ Cửa Sập đến Suối Lúa. Đoạn bị trượt lở bờ và bồi lắng lòng hồ yếu nhất thuộc đoạn thượng lưu hồ, từ Tạ Pú đến Hin Phá (Chiềng Hoa).

\section{Kết luận}

Trên hồ thủy điện Hòa Bình, lần đầu tiên đã ứng dụng phân tích viễn thám phân giải cao (VNREDSat-1, SPOT-5 và Landsat-8) và phân tích không gian trong môi trường GIS vào nghiên cứu đánh giá hiện trạng và mức độ TLBH.

Trên hồ Hòa Bình, mức độ TLBH phân thành 8 đoạn khác nhau. Các đoạn có mức độ trượt lở mạnh (mật độ trượt lở lớn $>4$ khối $/ \mathrm{km}$ ): từ Cửa Sập đến Suối Lúa và từ Yên Phong đến đập. Ở đây phân bố phần lớn các khối trượt có kích thước trung bình-lớn. Các đoạn có mức độ trượt lở trung bình (mật độ trượt lở trung bình, 2-4 khối $/ \mathrm{km}$ ): từ đập Sơn La đến Ít Ong, từ Hin Phá (Chiềng Hoa) đến Bản Khộc và từ $\mathrm{Ba} S \mathrm{Sel}$ đến Yên Phong. Trên các đoạn này phân bố các khối trượt có kích thước trung bình-nhỏ. Các đoạn có mức độ trượt lở thấp (mật độ trượt lở nhỏ, <2 khối $/ \mathrm{km}$ ): từ Ít Ong đến Hin Phá, từ Bản Khộc đến Cửa Sập và từ Suối Lúa đến $\mathrm{Ba}$ Sel. Trên các đoạn này chủ yếu phân bố các khối trượt nhỏ.

Mức độ bồi lắng lòng hồ Hoà Bình được phân thành 3 đoạn khác nhau: yếu, trung bình và mạnh. Mức độ bồi lắng yếu thuộc đoạn thượng lưu từ Bản Trang về đến Bản Khộc (có lượng bồi tích chiếm $6 \%$ lượng bồi tích trong hồ). Mức độ bồi lắng mạnh thuộc đoạn trung lưu từ Bản Khộc về đến Suối Lúa (lượng bồi tích chiếm $78 \%$ lượng bồi tích trong hồ). Mức độ bồi lắng lòng hồ trung bình thuộc đoạn hạ lưu từ suối Lúa về đến Đập (lượng bồi tích chiếm 16\% tổng lượng bối tích ở hồ).

Mức độ TLBH và BLLH phân thành 7 đoạn khác nhau. Đoạn hồ có mức độ TLBH và $B L L H$ rất mạnh từ Cửa Sập đến Suối Lúa; đoạn hồ có mức độ $\mathrm{TLBH}$ và $\mathrm{BLLH}$ mạnh từ Yên Phong đến đập; 2 đoạn hồ có mức độ TLBH và $B L L H$ trung bình: từ Bản Khộc đến Cửa Sập và từ $\mathrm{Ba}$ Sel đến Yên Phong; 3 đoạn có mức độ TLBH và $B L L H$ thấp: từ đập Sơn $\mathrm{La}$ đến Ít $\mathrm{Ong}$, từ Hin Phá đến Bản Khộc và từ Suối Lúa đến $B a$ Sel và đoạn hồ có mức độ $T L B H$ và $B L L H$ rất yếu từ Tạ Pú đến Hin Phá.

Công trình này được sự tài trợ của Đề tài VT/UD-03/13-15 do TS. Phạm Quang Sơn làm Chủ nhiệm, Viện Địa chất là Cơ quan chủ trì, tập thể tác giả xin chân thành cảm ơn.

\section{Tài liệu dẫn}

Nguyễn Tứ Dần và nnk, 2007: Sử dụng tư liệu viễn thám đa thời gian và GIS, nghiên cứu sự biến động lớp phủ trên lưu vực sông Đà góp phần giám sát bồi tích hồ Hòa Bình. Báo cáo tổng kết đề tài cấp Viện Khoa học và Công nghệ Việt Nam. Giai đoạn 2006 - 2007. Viện Hàn lâm Khoa học và Công nghệ Vệt Nam.

Richard, Jon A, 1986: Remote Sensing Digital Image Analysis - And Introduction. Springer, Verlag.

Sabins F.F, 1978: Remote Sensing - Principles and Interpretation. San Francisco.

Nguyễn Kiên Dũng, 2002: Nghiên cứu xây dựng cơ sở khoa học tính toán bồi lắng cát bùn hồ chứa Hòa Bình, Sơn La. Luận án tiến sĩ, Hà Nội.

Trần Trọng Huệ và nnk, 2000: Nghiên cứu đánh giá hiện tượng trượt lở khu vực mép nước hồ Hoà Bình, kiến nghị một số giải pháp phòng tránh. Báo cáo đề tài cấp Viện Hàn lâm KH\&CN Việt Nam.

Nguyễn Trọng Yêm và nnk, 2006: Nghiên cứu thành lập bản đồ tai biến thiên nhiên trên lãnh thổ Việt Nam. Báo cáo tổng kết đề tài, Viện Địa chất, Hà Nội.

Đào Văn Thịnh và nnk, 2005: Các tai biến địa chất ở Tây Bắc Bộ. Báo cáo tổng kết đề tài, Cục Địa chất và Khoáng sản Việt Nam, Hà Nội. 